\title{
Report on the Eggs and Larvæ of Teleostean Fishes observed at Plymouth in the Spring of 1902.
}

\author{
By
}

Frank Balfour Browne, M.A. (Oxon.).

In the following pages I have attempted, at Mr. Garstang's suggestion, to record the results of the examination of tow-net stages of Teleostean fishes, as it seemed important to determine to what extent the record for 1897, published by Holt and Scott (Journal M. B. A., v., N.S., p. 156), was representative of the conditions usually prevailing in the Plymouth district.

The work was begun in February, and the present paper deals with material taken up to the end of April, the collections being made, as a rule, at intervals of two or three days. So far, some interesting differences in the date of the first occurrence of several of the species from what was recorded in 1897 have been observed.

The first egg of Pleuronectes flesus was taken this year on February 21st, while in the 1897 record the date of the first capture of this egg was March 30th. It should be noted, however, that Holt and Scott record no observations between March 1st and 30th, so that the difference in date of appearance in this case (as in some others connected with the same period) may be more apparent than real.

P. microcephalus, first taken this year on February 21st, was found in 1897 on January 29th. This species has only occurred occasionally, usually one egg at a time, through the season, and appears to have been as seldom taken in 1897 .

There is no record in 1897 of the occurrence of the eggs of $P$. limanda. One was taken this year on April 14th, which produced a larva $2.63 \mathrm{~mm}$. in length, with pale yellow pigment, and a larva was also taken on April 21st $3.08 \mathrm{~mm}$. in length, showing the same colour.

Solea vulgaris has appeared this year two months earlier, and $S$. variegata, of which I have now had two eggs, three months earlier than in 1897. 
The eggs of Ctenolabrus rupestris, which Holt and Scott first record on April 27th, have only just made their appearance at the time of writing (May 23rd to 25th), and then in large numbers; while Trachinus vipera, which in 1897 did not occur until June 9 th, is recorded this year on April 9th. I have only had one egg of this species, but I think there can be little doubt as to its identity. It measured $1.43 \mathrm{~mm}$. in diameter, being larger than the extreme limit given by Holt (Trans. Roy. Dubl. Soc., iv. (1891), p. 437), who gives the limits of variation as $1.25-1.37 \mathrm{~mm}$. It had, however, about fifteen pale green oil globules scattered over the yolk, and the embryo and yolk immediately surrounding it was speckled with pigment which appeared dull yellow by reflected light.

No eggs have appeared this year up to the present corresponding with those recorded as Trigla gurnardus on March 30th, 1897.

In other respects my record agrees more or less closely with that of Holt and Scott.

I append a table showing the different times of appearance in the two years of the eggs above referred to.

\begin{tabular}{|c|c|c|c|c|}
\hline Species. & & $\begin{array}{l}\text { First occurrence } \\
\text { recorded in } 1897 \text {. }\end{array}$ & & $\begin{array}{l}\text { First occurrence } \\
\text { recorded in } 1902 \text {. }\end{array}$ \\
\hline Pleuronectes flesus & ${ }^{\circ}$ & . Mar. 30th & $\therefore$ & Feb. 21st. \\
\hline P. microcephalus & . & . Jan. 29th & $\ldots$ & Feb. 21st. \\
\hline P. limanda. & . & . not recorded & .. & Apr. 14th. \\
\hline Solea vulgaris & . & . Apr. 22nd & & Feb. 27th. \\
\hline S. variegata . & . & . July 27 th & $\ldots$ & Apr. 21st. \\
\hline Topknot (with larger & il globule) & . Feb. 15th & & Mar. 3rd. \\
\hline Topknot (with smaller & oil globule) & . Mar. 30th & & Mar. 15th. \\
\hline Gadus merlangus & . & . Mar. 30th & ... & Feb. 25th. \\
\hline Ctenolabrus rupestris & . & . Apr. 27th & $\ldots$ & (May 23rd.) \\
\hline Trachinus vipera & . & . June 3rd & $\ldots$ & Apr. 9th. \\
\hline Trigla gurnardus & . & . Mar. 30th & $\ldots$ & not yet recorde \\
\hline
\end{tabular}

Careful coloured drawings have been made of many of the eggs and larvæ recorded, and will, I hope, be useful for future reference.

Before discussing some of the more interesting points which have arisen in connection with the work, I wish to thank Mr. Garstang and Dr. Kyle for help and suggestions on many occasions.

\section{Callionymus.}

I obtained eggs of C. lyra first on February 14th, almost as soon as I commenced to examine the contents of the tow-nets.

The eggs measured varied in diameter between $\cdot 78$ and $93 \mathrm{~mm}$.:-

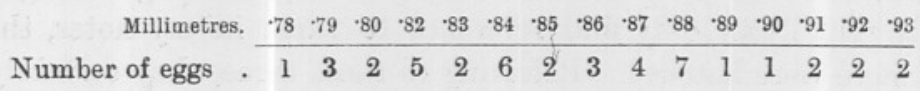


Twenty-three larvæ, measured within thirty-six hours of hatching, varied in length between 1.82 and $2.83 \mathrm{~mm}$.

I found most of these larvæ of the type figured by Holt in his paper in the Trans. Roy. Dubl. Soc., iv. (1891), Pl. LI., Fig. 41, but, at least in most cases, black pigment was present in addition to the yellow, as he has since recorded in this Journal (vol. v. (1897), p. 111).

I also hatched five larvæ from these eggs, which seemed to me to be of a different type from that referred to, but I am not prepared at present to give a final opinion.

\section{The Topknots-Zeugopterus and Phrynorhombus.}

In his paper in the M. B. A. Journal, v. p. 129, Holt, after discussing the facts then known as to the eggs and larvæ of the three British Topknots, concludes that his three Species x., xi. and xii., described in the Trans. Roy. Dubl. Soc., v. (1893), pp. 96, 99, and 101, had been separated on insufficient grounds.

I have had little material upon which to base conclusions, but such as I have had seems to fall conveniently into two series depending upon the size of the oil globule, as will be seen from the following table:-

\begin{tabular}{|c|c|c|c|c|c|c|c|c|}
\hline Millimetres. & es. $\quad \cdot 82$ & .85 & -87 & $\cdot 88$ & $\cdot 90$ & $\cdot 91$ & $\cdot 95$ & 97 \\
\hline Number of eggs. . & 4 & 1 & 1 & 2 & 5 & 1 & 1 & 1 \\
\hline Size of oil globule. & $\cdot 13-\cdot 15$ & $\cdot 12$ & $\cdot 12$ & $\cdot 12-\cdot 125$ & $\cdot 13-\cdot 14$ & $\cdot 14$ & $\cdot 18$ & $\cdot 14$ \\
\hline $\left.\begin{array}{l}\text { Larvæ hatched, } \\
\text { length in mm. }\end{array}\right\}$. & $2 \cdot 46$ & $2 \cdot 36$ & $2 \cdot 42$ & - & $\begin{array}{l}3 \cdot 37 \\
3 \cdot 1 \\
3 \cdot 0\end{array}$ & $3 \cdot 18$ & $3 \cdot 39$ & $2 \cdot 65$ \\
\hline Millimetres. & . 99 & $1 \cdot 02$ & 1.03 & 1.04 & $1 \cdot 05$ & 1.06 & 1.07 & 1.09 \\
\hline umber of eggs. & - 1 & 6 & 6 & 3 & 2 & 1 & 2 & 1 \\
\hline ze of oil globule. & $\cdot \quad \cdot 175$ & $\cdot 175-\cdot 19$ & $\cdot 18$ & $\cdot 19-\cdot 21$ & $\cdot 18-\cdot 185$ & $\cdot 195$ & $\cdot 18-\cdot 185$ & $\cdot 18$ \\
\hline $\begin{array}{l}\text { rvæ hatched, } \\
\text { agth in mm. }\end{array}$ & . $\quad-$ & $3 \cdot 57$ & - & 一 & $2 \cdot 88$ & - & - & 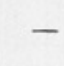 \\
\hline
\end{tabular}

Thus there seems to be a clear separation between eggs having an oil globule varying between 12 and 15 and others having an oil globule varying between 175 and $\cdot 21$, though the sizes of the eggs themselves give no clear line of demarcation.

The larvæ hatched from the eggs with the oil globule varying between 12 and 15 exactly resembled Species $\mathrm{F}$ of $\mathrm{M}$ 'Intosh and Prince (Trans. Roy. Soc. Edinb., xxxv., Pl. XVII., Fig. 4) and Holt's Species xii. (Trans. Roy. Dubl. Soc., v. (1893), Pl. VIII., Figs. 67 and 68). I did not, however, find any specimens which showed an imperforate anus, as in Holt's figure.

Of the larvæ hatched from the eggs showing the larger oil globule ( $\cdot 175$ to $\cdot 21)$ I can only find reference to three in my notes, though many more were hatched. Referring to these three, they certainly did 
not resemble those hatched from the other series of eggs, though it seemed to me that they might have been very well represented by the figures of either of Holt's Species x. or xi. (loc. cit., Pl. II., Figs. 19-21, Pl. VIII., Fig. 64), according as the light through the microscope was manipulated.

The eggs with the larger oil globule appeared in the tow-nets nearly a fortnight earlier than those with the smaller, the actual dates of their first occurrence being March 3rd for the former and March 15th for the latter. However, on March 7 th a female Zeugopterus norvegicus was dredged up from which eggs were obtained by slight pressure. These eggs appeared to be ripe, and floated in the sea-water, and were quite translucent. Those measured varied between 85 and $90 \mathrm{~mm}$. and the oil globule between $\cdot 13$ and $\cdot 14 \mathrm{~mm}$.

$\mathrm{My}$ facts are perhaps too few to permit a definite conclusion, but at least they suggest that the eggs with the smaller oil globule (Mr. Holt's Species xii.) are distinct from those with the larger globule (Mr. Holt's Species $\mathrm{x}$. and xi.), and that the former eggs belong to the smallest topknot, $Z$. norvegicus.

\section{Gadus.}

The descriptions given by the various authors of the eggs of the different species of the genus are up to the present insufficient for separating those of several of the commoner kinds, such as G. luscus, minutus. and pollachius. and possibly also some of those of G.merlangus.

In the first place certain eggs varying in diameter between 1.2 and $1.28 \mathrm{~mm}$. seemed to separate out clearly as those of $\mathbf{G}$. merlangus. Yellow pigment became early visible in the developing embryo, and the larvæ when hatched showed conspicuous yellow chromatophores all over the head, body, yolk sac, and dorsal and ventral fins. These eggs I have referred to in the record as those of G. merlangus. Twenty-two larvæ from these eggs were measured within thirty-six hours of hatching, and their length varied between 3.24 and $3.98 \mathrm{~mm}$., the commonest length being about $3.65 \mathrm{~mm}$.

About 115 other Gadus eggs were obtained, those measured varying in size between .90 and $1.19 \mathrm{~mm}$., as follows :-

\begin{tabular}{|c|c|c|c|c|c|c|c|c|c|c|c|c|c|}
\hline Size in millimetres. & $\cdot 90$ & 93 & 94 & $\cdot 95$ & $\cdot 96$ & $\cdot 98$ & $\begin{array}{r}\cdot 99 \\
\end{array}$ & $1 \cdot 0$ & $1 \cdot 01$ & $1 \cdot 02$ & 1.03 & $1 \cdot 05$ & 1.06 \\
\hline Number of eggs. & 1 & 3 & 2 & 6 & 1 & 9 & 3 & 14 & 2 & 4 & 2 & 1 & 1 \\
\hline etres. & 1.07 & $1 \cdot 08$ & 1.09 & $1 \cdot 1$ & $1 \cdot 11$ & $1 \cdot 12$ & $1 \cdot 13$ & $1 \cdot 14$ & $1 \cdot 16$ & $1 \cdot 17$ & $1 \cdot 18$ & $1 \cdot 19$ & 1.2 \\
\hline umber of eggs. & 2 & 2 & 1 & 3 & 1 & 1 & 3 & 1 & 1 & 2 & 2 & 1 & \\
\hline
\end{tabular}

I hatched many of these eggs, the larvæ varying as follows:-

\begin{tabular}{|c|c|c|c|c|c|c|c|c|c|c|c|c|}
\hline Size in $\mathrm{mm}$ & 95 & $\cdot 96$ & 97 & 98 & $\cdot 99$ & $1 \cdot 0$ & $1 \cdot 01$ & $1 \cdot 02$ & 1.08 & 1.09 & $1 \cdot 1$ & $1 \cdot 2$ \\
\hline & $3 \cdot 26$ & $2 \cdot 3$ & $2 \cdot 35$ & 30 & 3.07 & $3 \cdot 36$ & $3 \cdot 1$ & $2 \cdot 87$ & 3 . & $3 \cdot 2$ & $2 \cdot 7$ & 3.2 \\
\hline Length & & - & $3 \cdot 0$ & 3.07 & $3 \cdot 12$ & $3 \cdot 1$ & - & $3 \cdot 0$ & $3 \cdot 38$ & - & $3 \cdot 49$ & $3 \cdot 15$ \\
\hline $\begin{array}{c}\text { larvæ } \\
\text { in }\end{array}$ & & - & - & $3 \cdot 27$ & - & 3.07 & - & $3 \cdot 64$ & - & - & - & $3 \cdot 5$ \\
\hline & - & - & - & $2 \cdot 75$ & - & 3.1 & - & - & - & - & - & - \\
\hline lllimetres & - & - & E & $\begin{array}{r}3 \cdot 2 \\
-\end{array}$ & Z & $\begin{array}{l}3 \cdot 27 \\
3 \cdot 05\end{array}$ & $\overline{-}$ & $\overline{-}$ & $\overline{-}$ & $\overline{-}$ & $\overline{-}$ & - \\
\hline
\end{tabular}


These measurements were taken within thirty-six hours of the larva hatching. The total number of larvæ hatched and measured was forty-four, and their sizes varied between $2 \cdot 3$ and $3 \cdot 76$, but in all other cases than those given in the above table the larvæ could not be referred to particular eggs.

In most of the eggs when they reached their final stages a yellowish tinge was distinctly visible, and in some cases faint yellow pigment spots could be seen, and in all the larvæ produced either a yellowish tinge could be detected or yellow spots were visible just as in the larvæ hatched from eggs attributed to $G$. merlangus, but very faint. The degree of yellowness, however, was not the same in all cases, and in some the pigment spots only became visible when the larvæ were moribund, where before there had only been a faint yellow tinge. In these cases the spots were discernible all along the body and on the head, and in a few cases several spots could be made out on the yolk sac and at the extreme anterior end of the dorsal fin.

With regard to those larvæ which when healthy showed pale pigment dispersed as in $G$. merlangus, I did not have enough to ascertain certainly whether they only arose from the larger eggs. I find one record of an egg 1.09 which produced such a larva $3.2 \mathrm{~mm}$., and I had other such larvæ $3 \cdot 12,3 \cdot 12,3 \cdot 12,3 \cdot 45,3 \cdot 2,3 \cdot 2 \mathrm{~mm}$. in length. I kept four of these larvæ on April 12th, hatched from eggs taken on the 9 th, and also one larva of G. merlangus; and on April 14th the merlangus larva still showed strong yellow pigment spots, whereas the other three larvæ (one had died) had lost their distinct chromatophores and only showed a yellow tinge. It is on account of these larvæ that I said that possibly some of the eggs of $G$. merlangus were indistinguishable, and though from the size of the one egg given and from the different appearance of the larvæ they may be some other species than the whiting, there is, of course, nothing at present to draw conclusions from.

Heincke and Ehrenbaum (Eier und Larven von Fischen der deutschen Bucht, 1900, pp. 120 and 170) describe the pigmentation of the embryo pollack as being similar to that of $G$. ceglefinus and possessing black pigment only, arranged in a line down each side to the tail, and they distinguish $G$. luscus from $G$. pollachius by the presence of yellow pigment in the former. Now the pollack is an extremely abundant fish in the neighbourhood of Plymouth, and it would be strange indeed had I not obtained a few eggs at least of this species. Yet the only Gadus egg I have had which showed no trace of yellow was the egg of G. morrhua.

Of course, it must be borne in mind that the tow-nets examined have all, or nearly all, been taken within three or four miles of the shore, 
and in most cases much closer in, so that I may perhaps not have been on the right ground.

Holt (M. B. A. Journal, v., p. 141) refers to the eggs of pollack as being 1.4 to $1.45 \mathrm{~mm}$. in diameter and the larva hatched from one of these eggs as being $4.2 \mathrm{~mm}$. in length, and having "a single lateral row of stellate black chromatophores extending from the head to about midway along the tail." I have had no Gadus egg, except that of the cod, so large as those referred to by Holt, and in that case the larva resembled exactly the figure given by Masterman (M'Intosh and Masterman, Plate IX., Fig. 1) for a G. morrhua, and also agreed with Holt's description of the larva of that species (Trans. Roy. Dubl. Soc.).

Heincke and Ehrenbaum give the limits of size for G. pollachius eggs as $1 \cdot 10$ to 1.30 (perhaps $1 \cdot 45$ ), so that as far as size is concerned many of my eggs could quite well be those of this species. As to the arrangement of pigment in a single row along each side, many of my larvæ showed this when healthy; but when the black pigment spots became very dendritic, after a larva had been on the stage of the microscope for a few minutes, the regularity of the rows was far from obvious, and the pigment spots under these circumstances generally appeared to increase in number. As to the existence of the yellow tinge in my larvæ, I must admit that I was not always sure of its presence immediately the larva was placed under the microscope, but in such cases when it became obvious the larva was not necessarily at the point of death, as I often kept such specimens alive for hours afterwards.

As to the other two species, G. luscus and minutus, they both occur apparently commonly in the neighbourhood, and from descriptions the larvæ of both show yellow either diffuse or as spots. Holt suggests a later spawning period for the latter species, but I have had no opportunity for investigating this point.

The sizes of eggs taken in February varied between .98 and 1.09 , in March between 93 and 1.17 (one egg .90), and in April between 93 and $1 \cdot 19$.

It was perhaps rather strange finding a single egg of G. morrhua on March 15th in the West Channel. The egg was advanced in development, the free caudal portion just appearing. The larva escaped on the 16 th or $17 \mathrm{th}$, and on the latter date measured $4.71 \mathrm{~mm}$., the preanal region being $1.83 \mathrm{~mm}$. in length.

The larva exhibited the characteristic barred appearance, and the pigment was arranged precisely as in Masterman's figure referred to above.

As this was the only example I found, and as the egg was already 
far advanced in development when taken, it had probably drifted a considerable distance from the spawning grounds of the species and evidently out of the usual currents.

\section{Motella.-The Rocklings.}

I have had very many eggs which are certainly referable to species of this genus, but they have shown no distinguishable specific characters unless differences in the colour of the oil globules can be considered as such.

From the commencement of the work in February I found eggs with a colourless oil globule common in the tow-nets, and they continued to occur in numbers all through March and the first half of April, after which they gradually became scarcer, until at the end of the month they only appeared now and again.

On March 15th I first obtained a Motella egg with a greenish-yellow globule; and eggs with this character gradually became commoner as those with the colourless one began to diminish, until they took their place as the commonest egg in the tow-nets. These latter eggs were still quite common at the end of April, the point at which the present record ceases.

Only three times did I find eggs with a copper-coloured oil globule. On March 3rd they first appeared in numbers, this date happening to be one on which the egg with a colourless globule was also particularly abundant. I obtained on that date something over one hundred Motella eggs, those with the coloured globule being about equal in number with those having the colourless one.

Though the latter eggs were in all stages of development, none of those with the coloured globule had begun to segment. Of these latter eggs the majority had several small oil globules, many having five, and some even nine.

I reserved a batch of each variety of egg for hatching, placing them in similar vessels containing sea-water. As development proceeded the coloured globules in the one batch gradually became paler, until at the end of three days the colour could, in most cases, only be described as a smoky white. The globules had also generally reduced in number in each egg, one being present in the majority. None of this batch of eggs hatched, although nearly all the batch with colourless globules, about fifteen in number, hatched normally.

On March 11th I again obtained among eggs with the colourless globule a few with the coloured one, and I again endeavoured to hatch them. The colour of the oil globule gradually disappeared as before, but after developing to about the end of Stage II. the eggs again all died. 
On March 19th I again obtained a single egg with copper-coloured globule, but it also failed to hatch.

Holt obtained eggs with colourless, "and some few with distinctly cupreous globules," from one specimen of $M$. mustela, so that the colour, not being present in all the eggs, is evidently not characteristic; and from the fact that out of perhaps twenty-five eggs with this distinction I could not get one to hatch it occurred to me that the colour might be indicative of some pathogenic condition. Unfortunately material did not suffice to make further investigations on this point.

The eggs with the green oil globule always developed normally, producing a larva with the same character but otherwise quite similar to larvæ hatched from eggs with the colourless globule. This was as Holt found.

On several occasions I have come across eggs with a large number of colourless oil globules of various sizes, the eggs having a perivitelline space, but never showing any signs of development. The globules in many cases ran together in the course of a few days, but the eggs were infertile. Holt also found these eggs and obtained them directly from a female Motella mustela.

On April 9th a ripe female Motella $19 \mathrm{cms}$. long was brought to me, which proved to be a specimen of $M$. fusca (Moreau), a description of which will be found on another page. Large numbers of eggs had been extruded in the handkerchief in which the fish was carried, and many more were obtained from the fish by slight pressure. These eggs exactly agreed with the infertile eggs above referred to. The size varied between 69 and $82 \mathrm{~mm}$. diameter, the majority of those measured, however, being about 72 to $74 \mathrm{~mm}$.; and the oil globules, in a few in which only one was present, measured 13 to $14 \mathrm{~mm}$.

Brook gives the size of fertilised eggs of $M$. mustela as 65 to 73 longer axis, and 64 to 716 shorter axis with an oil globule of about 11 . The eggs of $M$. fusca, therefore, appear to be slightly larger, with a larger oil globule than those of the former species, but there is probably not sufficient difference to distinguish between tow-net eggs.

Holt found the size of the eggs with a greenish globule, which he mentions in his Irish papers (Trans. Roy. Dubl. Soc., ii. (1891), p. 464, and v. (1893), p. 95 ) as $\cdot 66$, with o.g. $\cdot 14$, and $\cdot 72$, o.g. $\cdot 17$, and I find that those I have obtained this year here vary between 69 and 82 , o.g.'s 14 and 20 . The eggs with the colourless globule vary from $\cdot 70$ to 87 , o.g. $\cdot 12$ to $\cdot 19$.

Unless, therefore, the green oil globule can be taken as a specific 
distinction, there is no evidence at present upon which to identify any of the tow-net eggs with any particular species.

I append tables of the number of eggs at the different sizes which I have obtained, of which I have actual measurement. In many cases I had only recorded that the sizes of a batch obtained varied between two limits, so that these are not included in the tables.

Motella. Table showing number of eggs measured and sizes.

I. Eggs with Colourless and Copper-coloured Oil Globules. $\begin{array}{llllllllllllllllll}\text { Millimetres. } & 70 & 71 & 72 & \cdot 73 & 74 & 75 & 76 & -77 & 78 & 79 & -80 & -81 & -82 & -83 & 86 & -87\end{array}$

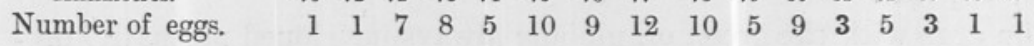

II. Eggs with Green or Greenish-yellow Globules. Millimetres. $\quad \begin{array}{rrrrrrrrrrrrr}69 & 70 & 71 & 72 & -73 & 74 & 75 & -76 & -78 & -80 & -82\end{array}$

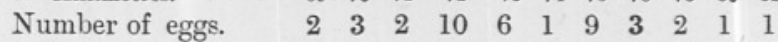




\section{JOURNAL OF OBSERVATIONS,}

February to April (Inclusive), 1902.

Abbreviations employed : sev. = several ; m. = many ; v.m. = very many ; o.g. $=$ oil globule.

For convenience of tabulation the different stages of development have been divided into three groups: Stage I. = if fertilised, stages up to the outgrowth of the eyes ; II. = from I. up to the appearance of the caudal rudiment ; III. = from II. up to hatching.

Since the ova were not always examined immediately after their capture, it was necessary in many cases to compute the stage exhibited at that time. The divisions indicated above being fairly broad, the results set forth below are probably near the mark. Confusion is most liable to have occurred between Stages II. and III. All dimensions are given in millimetres.

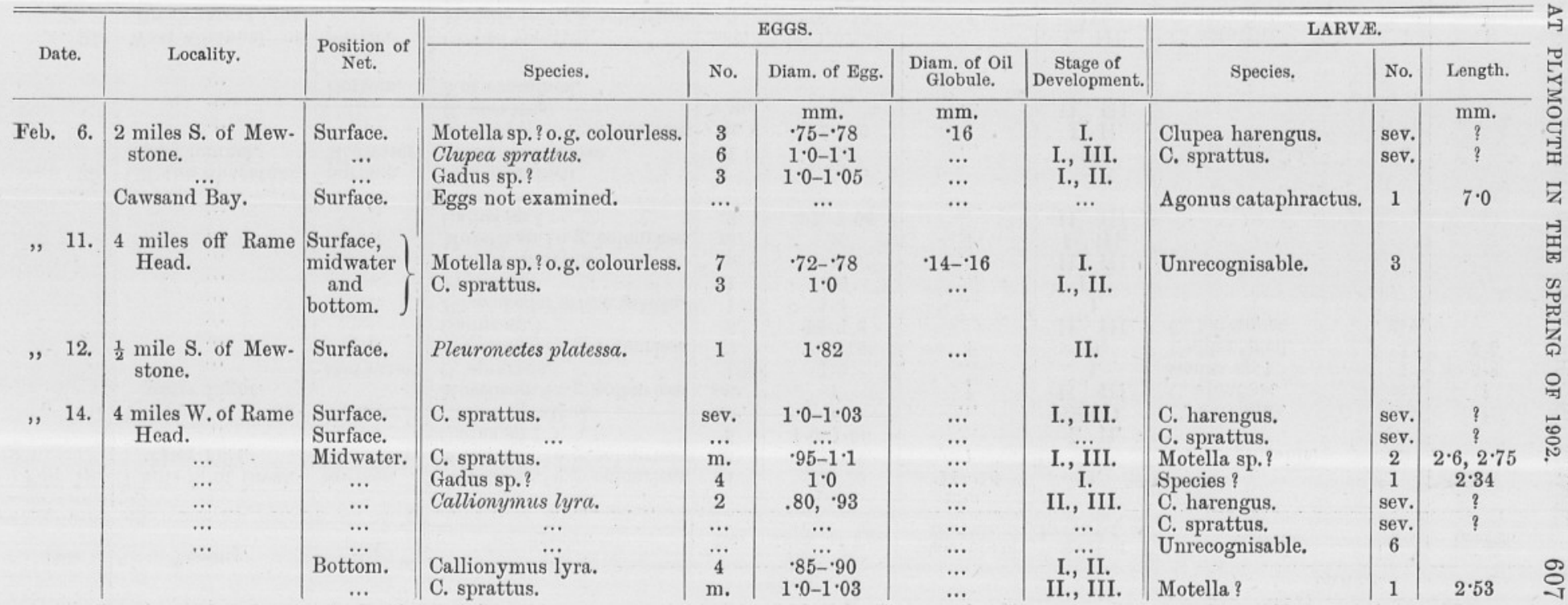




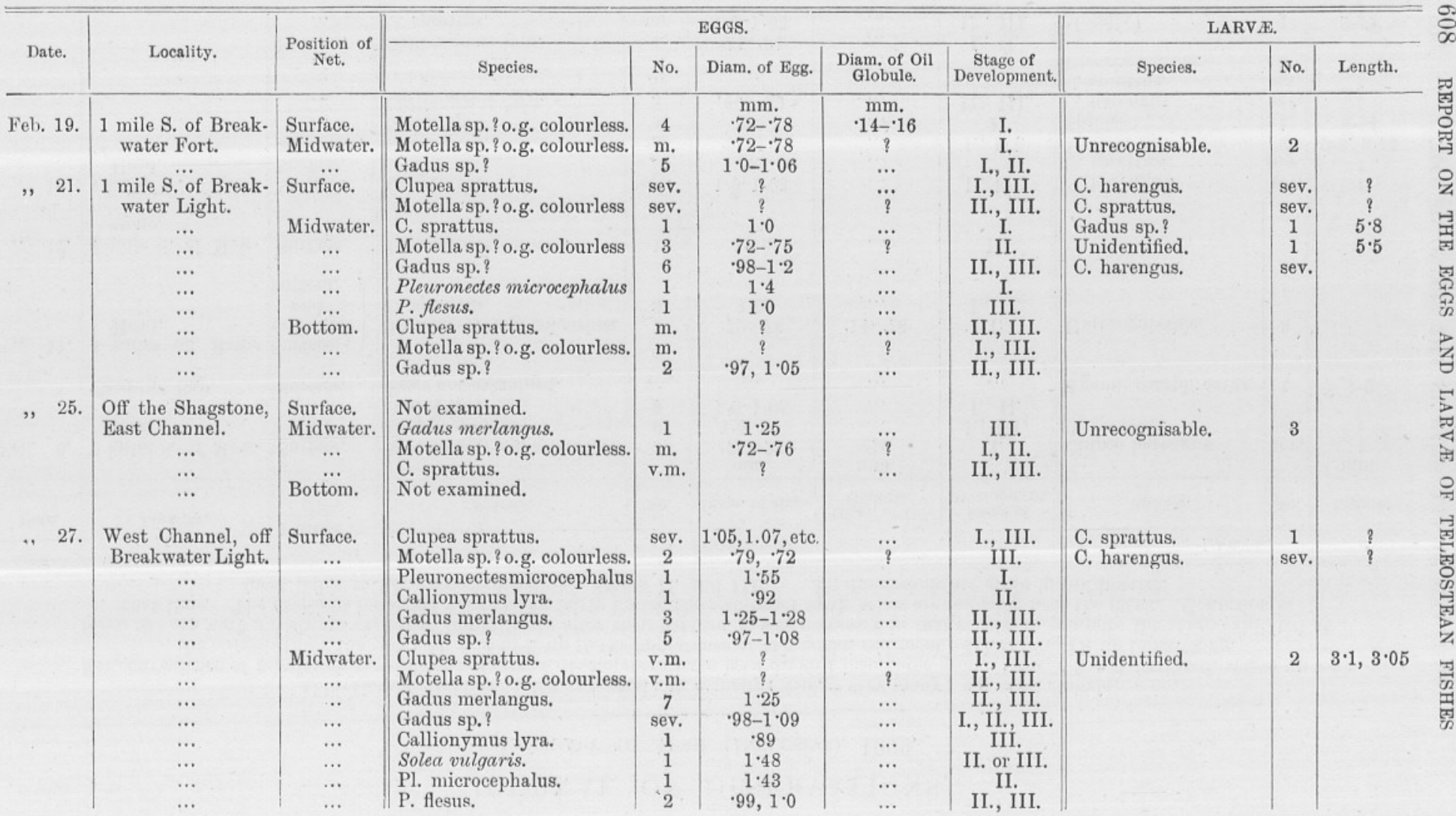




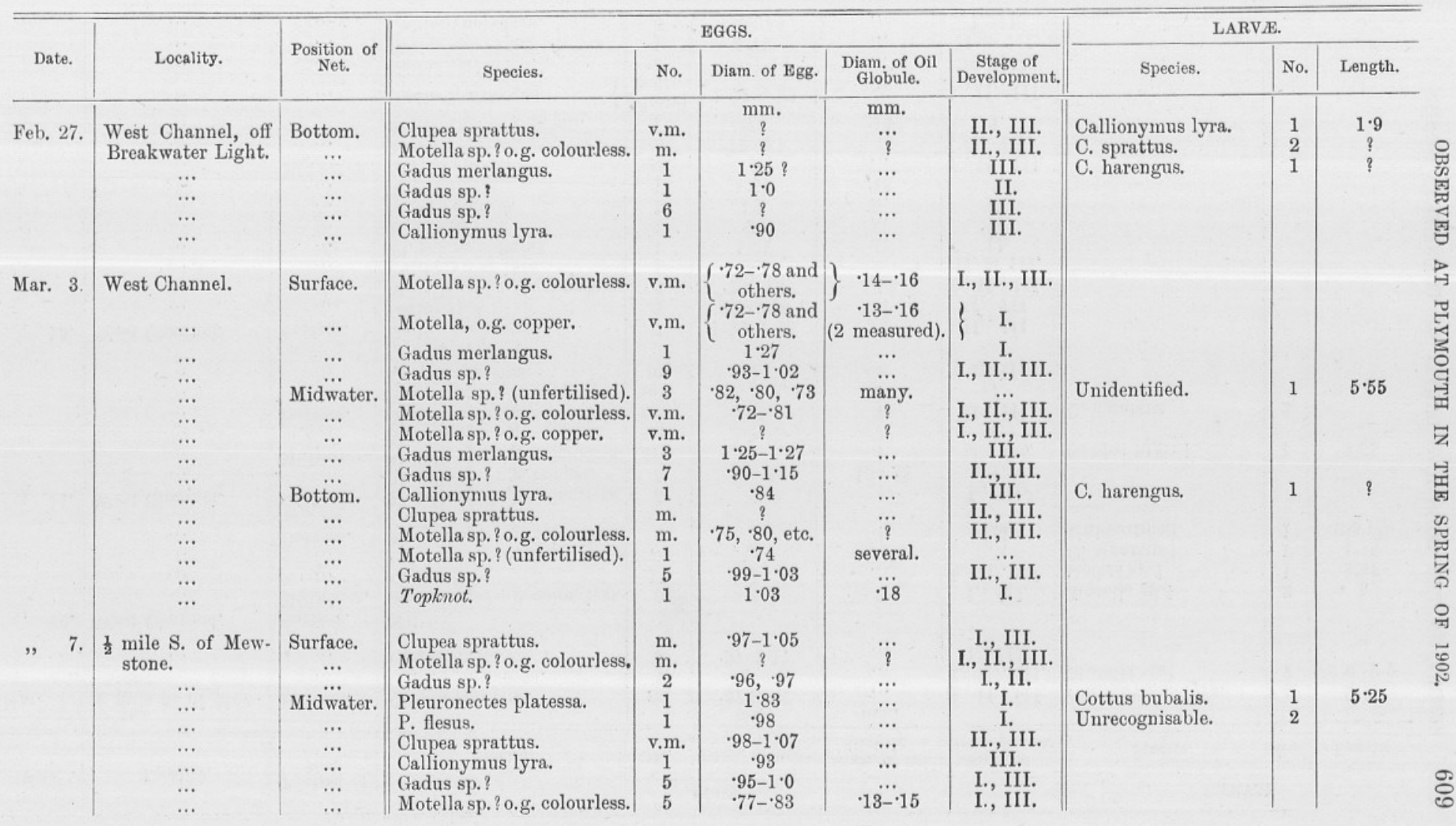

: 


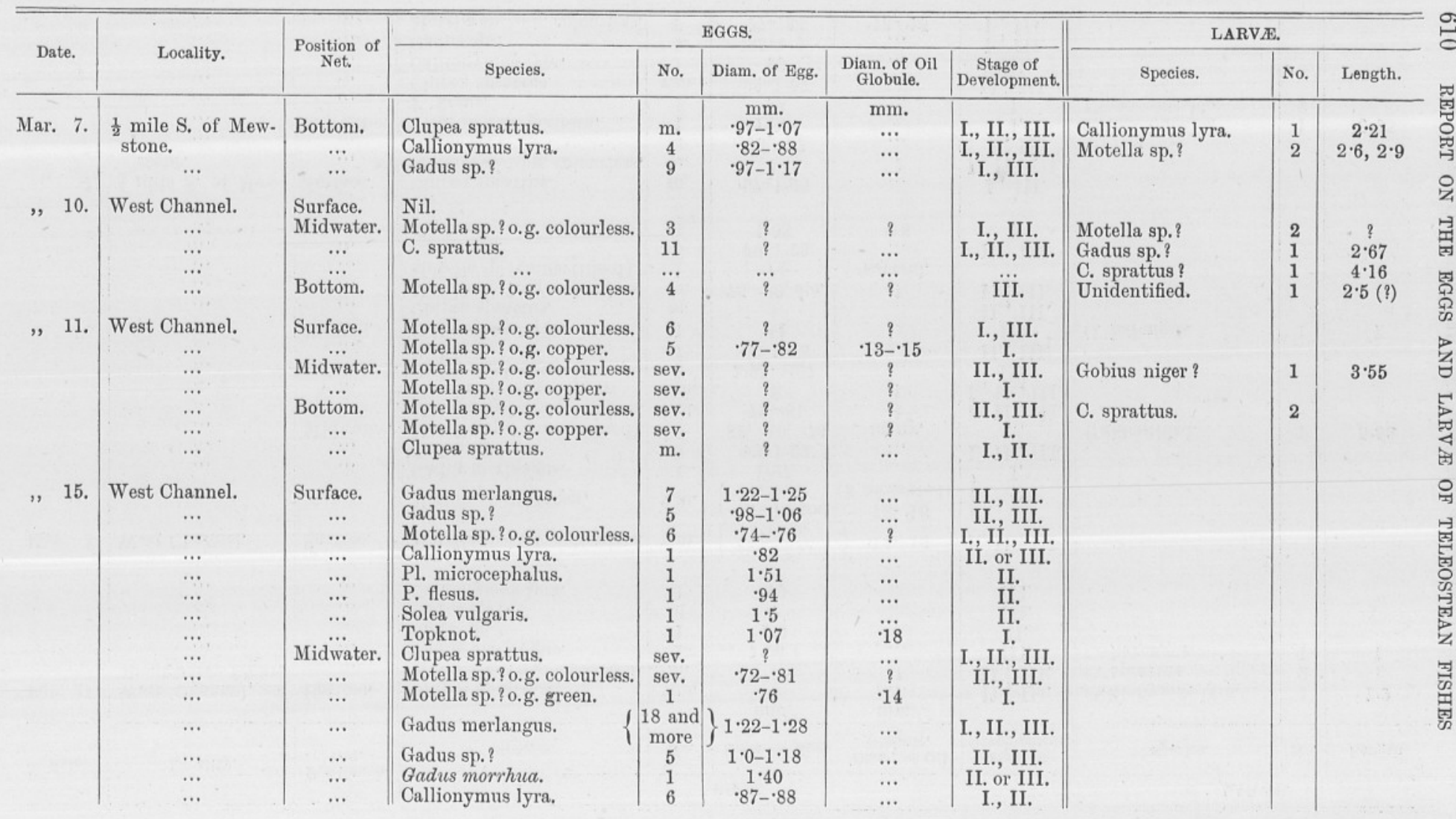




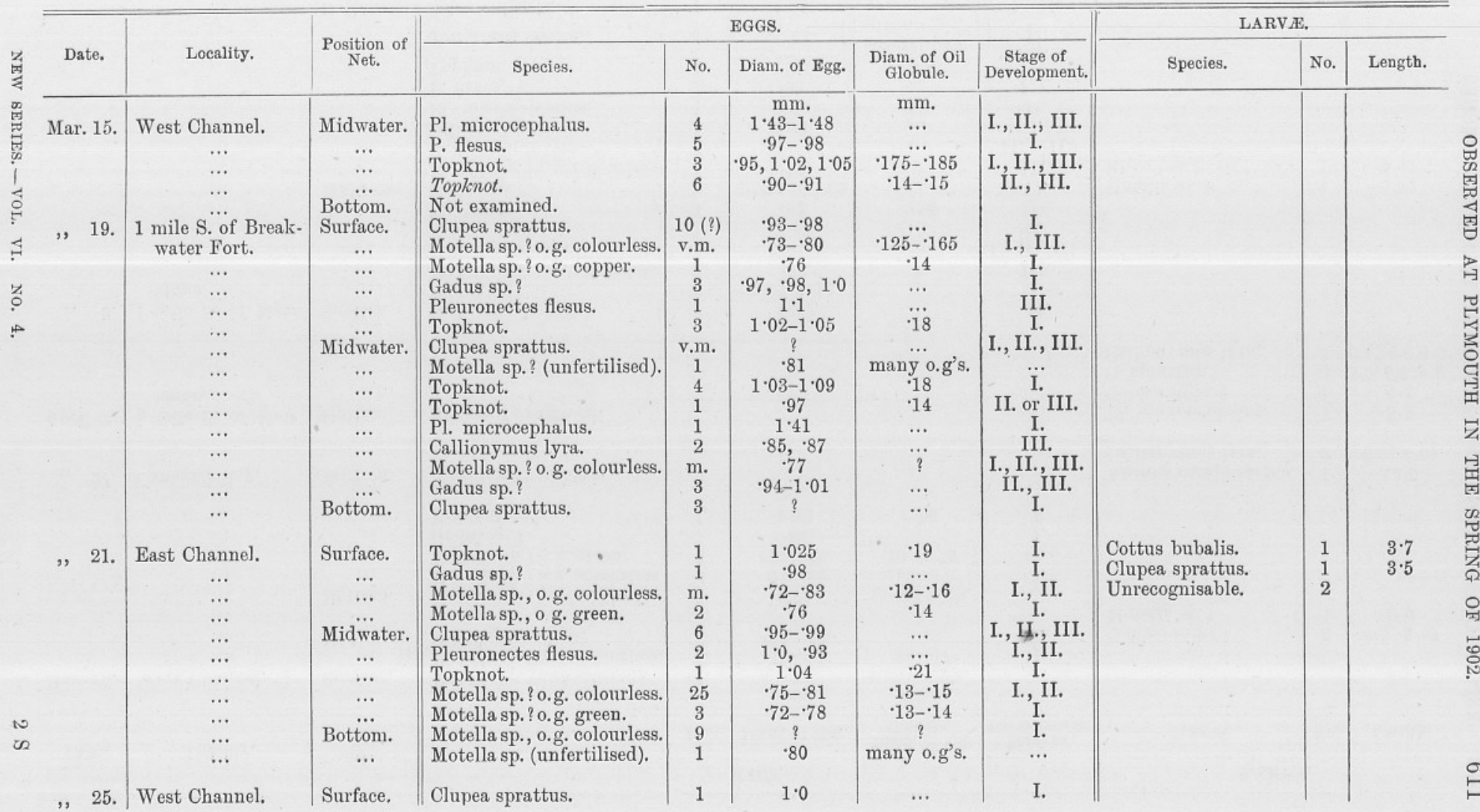




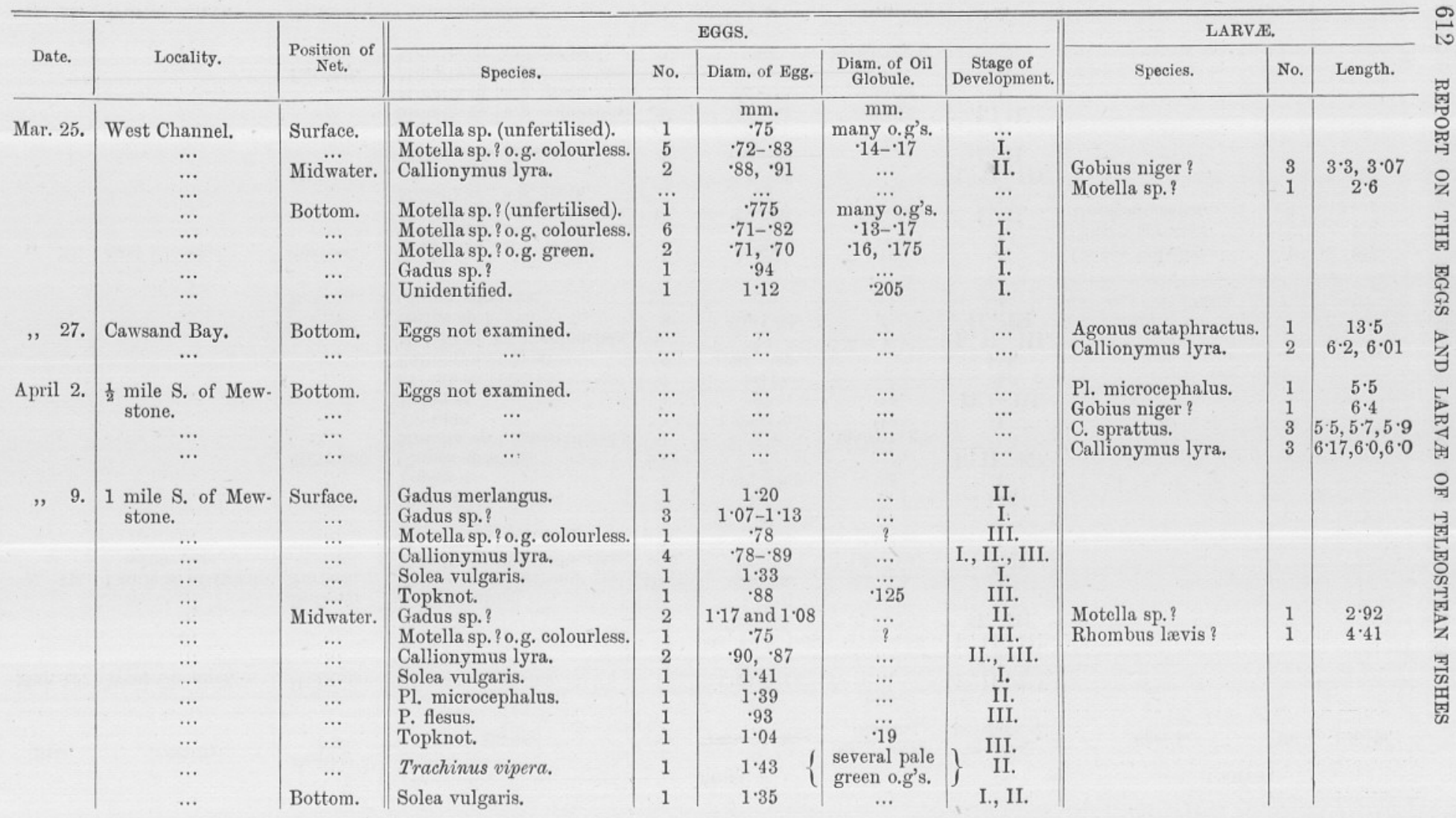




\begin{tabular}{|c|c|c|c|c|c|c|c|c|c|c|}
\hline \multirow[b]{2}{*}{ Date. } & \multirow[b]{2}{*}{ Locality. } & \multirow{2}{*}{$\begin{array}{l}\text { Position of } \\
\text { Net. }\end{array}$} & \multicolumn{5}{|c|}{ EGGS. } & \multicolumn{3}{|c|}{ LARV尺. } \\
\hline & & & Species. & No. & Diam. of Egg. & $\begin{array}{l}\text { Diam. of Oil } \\
\text { Globule. }\end{array}$ & $\begin{array}{c}\text { Stage of } \\
\text { Development. }\end{array}$ & Species. & No. & Length. \\
\hline April 9. & 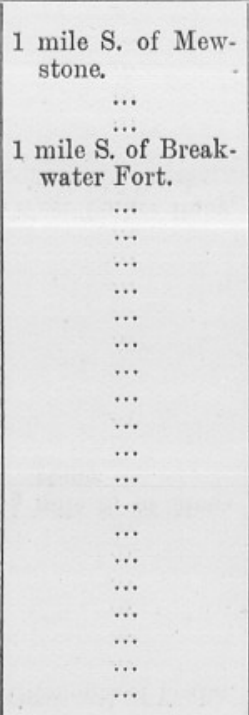 & $\begin{array}{c}\text { Bottom. } \\
\ldots \\
\ldots \\
\ldots \\
\text { Surface. } \\
\ldots \\
\ldots \\
\ldots \\
\ldots \\
\ldots \\
\ldots \\
\text { Midwater. } \\
\ldots \\
\ldots \\
\ldots \\
\ldots \\
\ldots \\
\ldots \\
\text { Bottom. } \\
\ldots \\
\ldots \\
\ldots \\
\ldots \\
\ldots \\
\ldots\end{array}$ & $\begin{array}{l}\text { Pl. microcephalus. } \\
\text { Clupea sprattus. } \\
\text { Callionymus lyra. } \\
\text { Gadus sp.? } \\
\text { Gadus sp.? } \\
\text { Motella sp.? o.g. colourless. } \\
\text { Motella sp.? o.g. green. } \\
\text { Clupea sprattus. } \\
\text { Callionymus lyra. } \\
\text { Pleuronectes flesus. } \\
\text { Topknot. } \\
\text { Clupea sprattus. } \\
\text { Callionymus lyra. } \\
\text { Topknot. } \\
\text { Gadus sp.? } \\
\text { Motella sp.? o.g. colourless. } \\
\text { Motella sp.? o.g. green. } \\
\text { Motella sp.? (unfertilised). } \\
\text { Clupea sprattus. } \\
\text { Callionymus lyra. } \\
\text { Topknot. } \\
\text { Topknot. } \\
\text { Motella sp.? o.g. green. } \\
\text { Gadus sp.? } \\
\text { Gadus merlangus. }\end{array}$ & $\begin{array}{l}1 \\
1 \\
3 \\
3 \\
2 \\
4 \\
2 \\
2 \\
2 \\
3 \\
2 \\
1 \\
2 \\
1 \\
1 \\
2 \\
2 \\
1 \\
2 \\
1 \\
2 \\
1 \\
1 \\
3 \\
1\end{array}$ & $\begin{array}{c}\text { mm. } \\
1.3 \\
? \\
? \\
1 \cdot 03-1 \cdot 135 \\
\cdot 97,1 \cdot 16 \\
\cdot 70-\cdot 82 \\
\cdot 69 \\
1 \cdot 0,1 \cdot 03 \\
\cdot 79 \\
\cdot 94, \cdot 95, \cdot 97 \\
\cdot 86, \cdot 88 \\
1 \cdot 08 \\
\cdot 83, \cdot 84 \\
\cdot 82 \\
1 \cdot 19 \\
76, \cdot 79 \\
\cdot 73, \cdot 715 \\
\cdot 75 \\
1 \cdot 03,1 \cdot 05 \\
? \\
82, \cdot 87 \\
\cdot 99 \\
\cdot 70 \\
\cdot 93-\cdot 97 \\
1 \cdot 23\end{array}$ & $\begin{array}{c}\mathrm{mm} . \\
\ldots \\
\ldots \\
\ldots \\
\ldots \\
\ldots \\
\cdot 13-16 \\
\cdot 17 \\
\ldots \\
\ldots \\
\ldots \\
\cdot 12 \\
\ldots \\
\ldots \\
\cdot 14 \\
\ldots \\
\cdot 13 \\
17, \cdot 16 \\
\text { many } 0 . \mathrm{g} \cdot \mathrm{s} . \\
\ldots \\
\ldots \\
\cdot 13, \cdot 12 \\
\cdot 175 \\
\cdot 14 \\
\ldots \\
\ldots\end{array}$ & \begin{tabular}{|l} 
I. \\
III. \\
II., III. \\
I., II. \\
II., III. \\
I., II., III. \\
I. \\
II. \\
I. \\
II., III. \\
II., III. \\
I. \\
II. \\
II. \\
II. \\
I. \\
I., II. \\
II. \\
III. \\
III. \\
II. \\
II. \\
I. \\
II. \\
II.
\end{tabular} & $\begin{array}{l}\text { Gobius niger ? } \\
\text { Callionymus lyra. }\end{array}$ & $\begin{array}{l}2 \\
1\end{array}$ & $\begin{array}{c}3 \cdot 5,3 \cdot 6 \\
3 \cdot 2\end{array}$ \\
\hline , 14 & $\begin{array}{c}1-3 \mathrm{~m} . \mathrm{S} \text {. to W.S.W. } \\
\text { of Mewstone. } \\
\ldots \\
\ldots \\
\ldots \\
\ldots \\
\ldots \\
\ldots\end{array}$ & $\begin{array}{c}\text { Surface. } \\
\quad \ldots \\
\ldots \\
\ldots \\
\text { Midwater. } \\
\ldots \\
\ldots \\
\ldots\end{array}$ & $\begin{array}{l}\text { Callionymus lyra. } \\
\text { Topknot. } \\
\text { Motella sp.? o.g. colourless. } \\
\text { Gadus sp.? } \\
\text { Gadus sp.? } \\
\text { Pleuronectes limanda. } \\
\text { Callionymus lyra. } \\
\quad . . .\end{array}$ & $\begin{array}{l}3 \\
1 \\
1 \\
2 \\
3 \\
1 \\
4 \\
\cdots\end{array}$ & $\begin{array}{c}\cdot 84-86 \\
1: 02 \\
\cdot 77 \\
1 \cdot 02,1 \cdot 14 \\
? \\
\cdot 81 \\
83-86 \\
\ldots\end{array}$ & $\begin{array}{l}\dddot{18} \\
114 \\
\cdots \\
\cdots \\
\cdots \\
\cdots\end{array}$ & $\begin{array}{l}\text { I., III. } \\
\text { I. } \\
\text { I. } \\
\text { I. } \\
\text { III. } \\
\text { III. } \\
\text { III. } \\
\quad \ldots\end{array}$ & $\begin{array}{l}\text { Clupea harengus. } \\
\text { Callionymus lyra. } \\
\text { Callionymus lyra. } \\
\text { Clupea harengus. } \\
\text { C. sprattus. } \\
\text { Motella sp.? }\end{array}$ & $\begin{array}{c}\text { sev. } \\
1 \\
2 \\
1\end{array}$ & $\begin{array}{c}3 \cdot 7-4 \cdot 3 \\
? \\
? \\
2 \cdot 8\end{array}$ \\
\hline
\end{tabular}




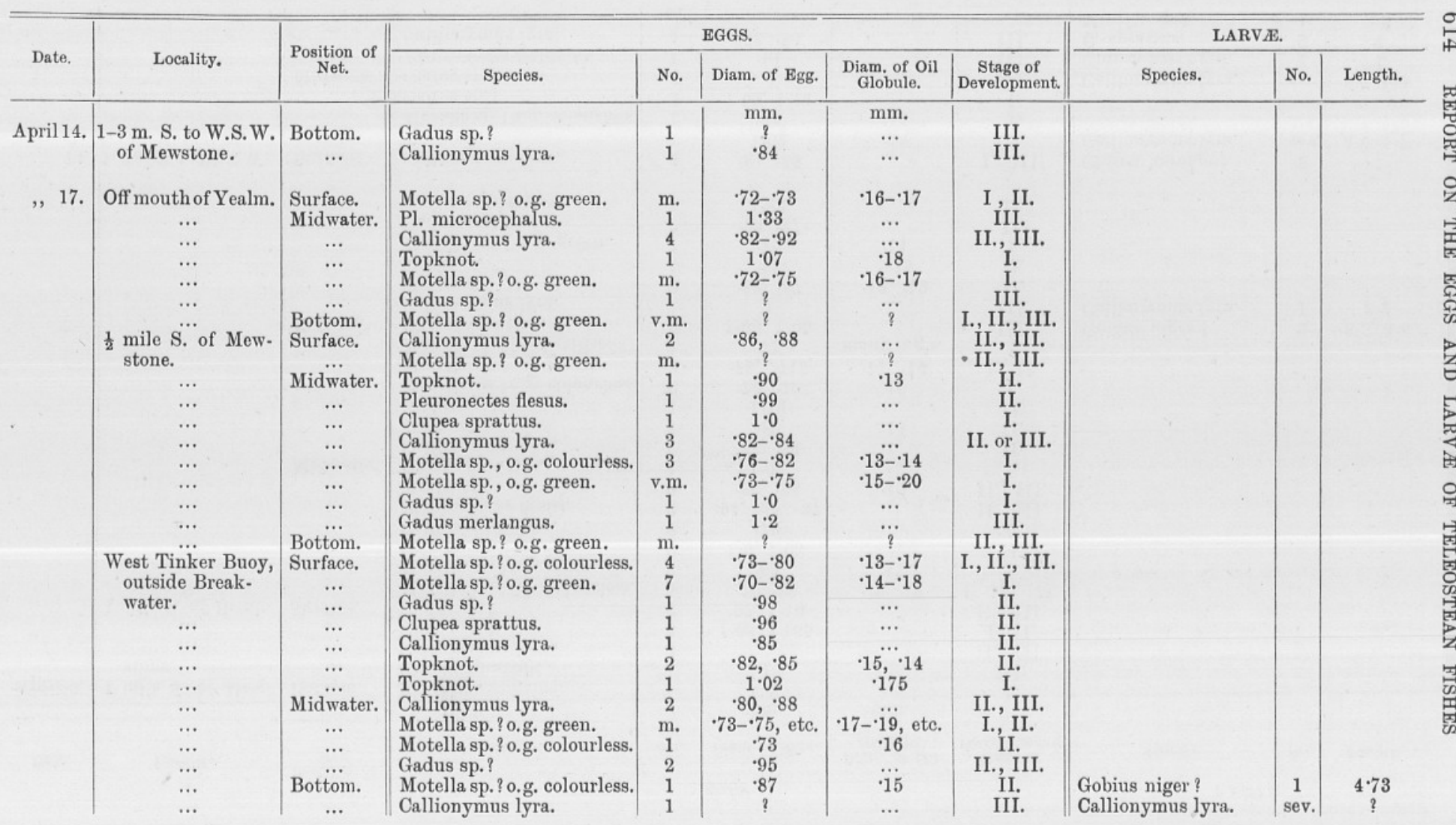




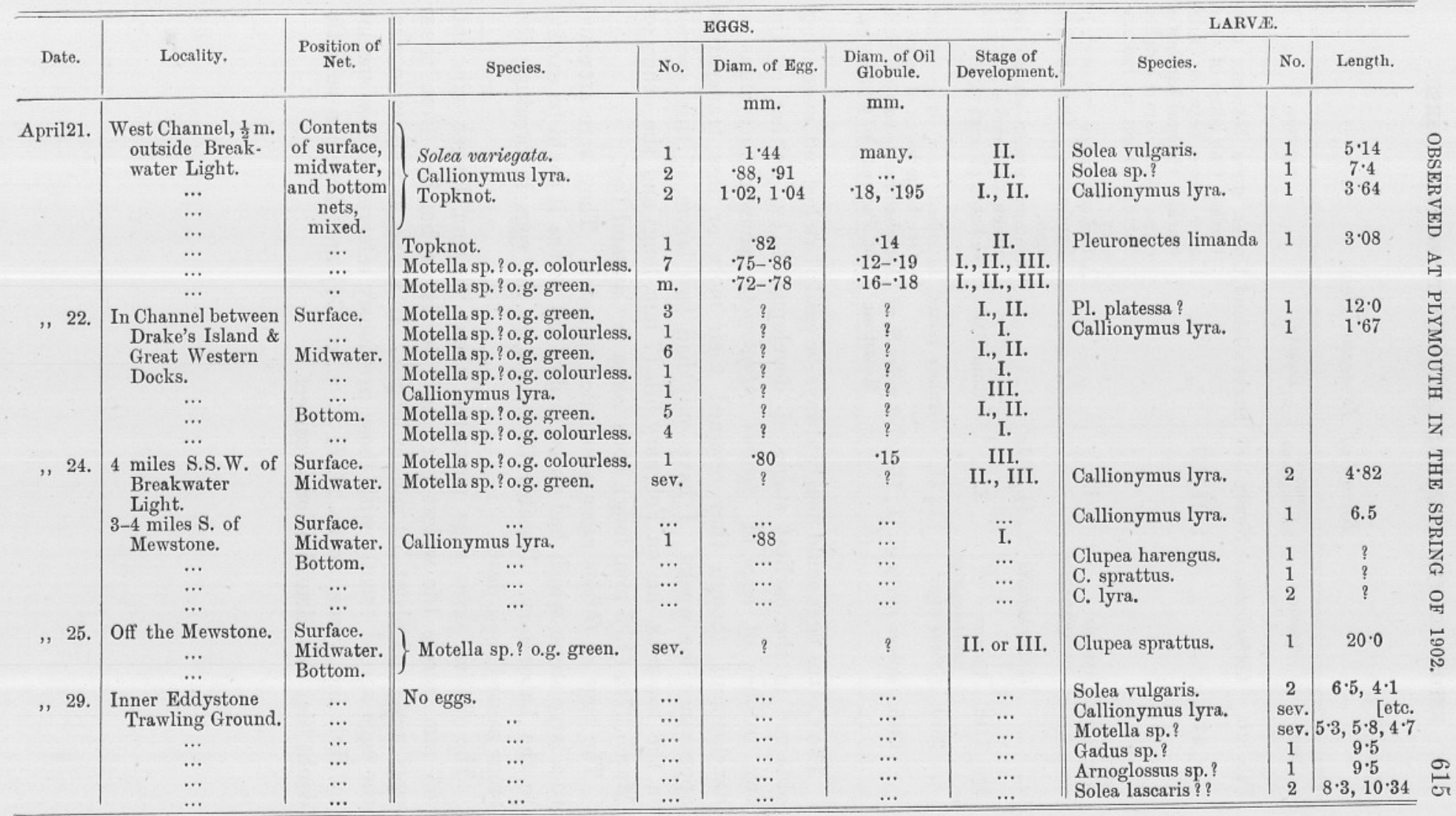


Record of Demersal Eggs.

\begin{tabular}{|c|c|c|c|c|}
\hline Date. & Species. & $\begin{array}{c}\text { Stage of } \\
\text { Development. }\end{array}$ & Locality. & Situation. \\
\hline Feb. 8th. & Cottus bubalis & Newly laid & Drake's Island & Under stone between tide- \\
\hline " 24th. & $" \quad "$ & I., II., III. & " & $\begin{array}{l}\text { Under stone between tide- } \\
\text { marks. Several batches of } \\
\text { eggs. Some larvæ hatched } \\
\text { during transit to Labora- } \\
\text { tory. }\end{array}$ \\
\hline Mar. 11th. & $\begin{array}{l}\text { Agonus } \\
\text { cataphractus }\end{array}$ & I. & " & $\begin{array}{l}\text { Attached under "roots" of } \\
\text { Laminaria. One batch of } \\
\text { eggs. }\end{array}$ \\
\hline " & Cottus bubalis & I., II., III. & $"$ & $\begin{array}{l}\text { Common under stones be- } \\
\text { tween tidemarks. }\end{array}$ \\
\hline Apr. 11th. & $\begin{array}{l}\text { Agonus } \\
\text { cataphractus }\end{array}$ & I. & Rum Bay & One batch of eggs (?). \\
\hline$" \quad 23 \mathrm{rd}$ & Gobius niger & I., II. & Drake's Island & $\begin{array}{l}\text { Attached to a large stone. } \\
\text { One large batch of eggs. }\end{array}$ \\
\hline " 24th. & Gobius pictus & I., II. & $\begin{array}{l}3 \text { miles S. of } \\
\text { Mewstone }\end{array}$ & $\begin{array}{l}\text { Attached inside valve of shell } \\
\text { of Pectunculus glycimeris. }\end{array}$ \\
\hline
\end{tabular}

The Cottus eggs could nearly always be easily hatched out, even when obtained in the earliest stages of development, but neither of the two batches of eggs of Agonus cataphractus showed any signs of development, though they retained their more or less transparent appearance for weeks. I have only had two larvæ of this species in the tow-nets, one on February 6 th $(7 \mathrm{~mm}$. long) and the other on March 27th (13.5 mm. long), both taken in Cawsand Bay.

The eggs of Gobius niger also failed to hatch. They were attached to a large stone, which had to be broken up before it could be carried to the Laboratory. Possibly the shock to the eggs in breaking the stone caused their death.

The Gobius pictus eggs measured about $80 \mathrm{~mm}$. longer axis and $63 \mathrm{~mm}$. across the widest part, and the larvæ hatched from these eggs measured about $3.0 \mathrm{~mm}$. in length. In shape, as well as in size, the eggs agreed exactly with those previously referred to this species by Holt and Byrne (Journ. M. B. A., v., p. 336), and there can be little doubt that this identification is correct. 